\section{Tourism innovation in the forestry sector: comparative analysis between Auckland Region (New Zealand) and Trentino (Italy)}

\author{
Sandra Notaro ${ }^{(1)}$, Alessandro Paletto ${ }^{(2)}$, Marika Piffer $^{(1)}$
}

Innovation is a primary aspect of economic growth and development and depends on the ability of entrepreneurs to create economic value by introducing new products or services, designing different production processes or rearranging organisational practices. The spreading of innovation is a key element in all economic sectors, including the forestry sector. Four types of innovation can be found in the forestry sector: product innovations (e.g., wood assortments), service innovations (e.g., biodiversity conservation and forest recreation), technological innovations (e.g., the introduction of new machinery, such as harvesters, processors or forwarders) and organisational innovations (e.g., changes in the production process or in the firm's organisational structure). In this paper, we focus on service innovations linked to tourism and recreation in the forest using a comparative investigation. In particular, three types of recreational innovations in the forest (adventure parks, educational farms, and cultural attractions) were analysed within two case studies located poles apart (Auckland Region in New Zealand and Trentino in Italy). The results of a questionnaire, submitted during face-to-face interviews, to a sample of New Zealand and Italian entrepreneurs indicated the level of innovation in the forestry sector, the elements of weakness and strength of the innovation process, and the potential of the transferability of novelties into each of the two contexts.

Keywords: Forestry Innovation System, Entrepreneurship, Tourism and Recreation in Forest

\section{Introduction}

Innovation can be defined as the result of new combinations of products, processes, markets, sources of supply, and organisations (Schumpeter 1911). Classical economists focused on the theoretical frame of innovation (Malerba 2000, Kurz 2010). In particular, Adam Smith considered technical

$\square$ (1) Department of Economics, University of Trento, v. Inama 5/I, I-38122 Trento (Italy); (2) Forest Monitoring and Planning Research Unit, Agricultural Research Council (CRA-MPF), p.za Nicolini 6, I-38122 Villazzano (TN - Italy)

(a) Alessandro Paletto

(alessandro.paletto@entecra.it)

Received: Jul 31, 2012 - Accepted: Oct 02, 2012

Citation: Notaro S, Paletto A, Piffer M, 2012. Tourism innovation in the forestry sector: comparative analysis between Auckland Region (New Zealand) and Trentino (Italy). iForest 5: 262-271 [online 2012-10-24] URL: http://www.sisef. it/iforest/ contents?id=ifor0631-005

Communicated by: Marco Borghetti progress, embodied in capital assets, which would lead to labour specialisation and consequently to productivity increase (in Malerba 2000). David Ricardo analysed the technical change tracing the relation among innovation, reduction in prices and increase in demand, which appears to have some influence on the employment level (in Kurz 2010). Karl Marx emphasised instead the social origin of innovation, which is supposed to be generated not by inventors but due to a social process consisting of struggles between opposing interests (in Kurz 2010). After the preliminary analysis of the concept of innovation by the classical economics school, in the 1950s, the economics of innovation as an autonomous discipline was born due to the work of Robert Solow (1957).

In recent decades, economists have considered innovation to be the engine of economic growth and the result of the interaction between a variety of actors who create and use technology and customers who demand products (Rametsteiner \& Weiss 2006a). Innovation denotes the successful introduction of novelties and can be viewed as a result of the common effort of two types of actors: entrepreneurs and institutions
(Sálka et al. 2006). This new approach to innovation analysis is based on the concept of systems of innovation (SIs), which can be defined as all the important economic, social, political, organisational factors that influence the development, diffusion, and use of innovations (Edquist 1997). From this point of view, the innovation process can be analysed through a linear or a non-linear (circular) model. For the linear model, innovations are developed by scientists, disseminated through intermediaries, and then implemented by users (i.e., entrepreneurs). The innovation-decision process is characterised by five stages: knowledge, persuasion, decision, implementation, and confirmation (Rogers 2002), each of which produces outputs that are transferred to the next stage as inputs (Weber \& Hemmelskamp 2005). Rogers (2003) stated that the process entails a progression whereby an actor passes from gaining initial knowledge of an innovation to forming an attitude towards it, to making the decision to adopt or reject it, to implementing it, and to confirming this decision. The critics of the linear model suggested the circular (non-linear) model (Kline \& Rosenberg 1986), which allows for feedback mechanisms and interactive relationships involving science, technology, learning, production and demand.

Systems of innovation can be studied also considering the key actors involved in the process: the entrepreneur, who is considered a creative destructor as well as the engine of innovation (Sálka et al. 2006) and the institutions, with rules, laws and regulations that set the relations and interactions between individuals, groups and organisations (Edquist \& Johnson 1997).

Even if the types of innovation are extremely complex and heterogeneous, in the literature the innovations can be divided into two main categories (Rametsteiner \& Weiss 2006b): process and product innovations. Process innovations include organisational and technological innovations. Normally, in the forestry sector, the last type of innovation includes the induction and diffusion of new machinery or technology in forest harvesting and processing, such as a new harvester or processor. Process innovations are driven primarily by improvements in the efficiency of production (Utterback \& Abernathy 1975) and secondarily in the quality of the products. Product innovations are concentrated in the market and are mainly customer driven and include the development of new goods and services (Làskovà \& Posavec 2011). In forestry, product innovations comprise innovative and marketable wood assortments or competitive products obtained with reduced costs (Duduman \& Bouriaud 2007), whereas service innovations consist of the transformation of forest ser- 


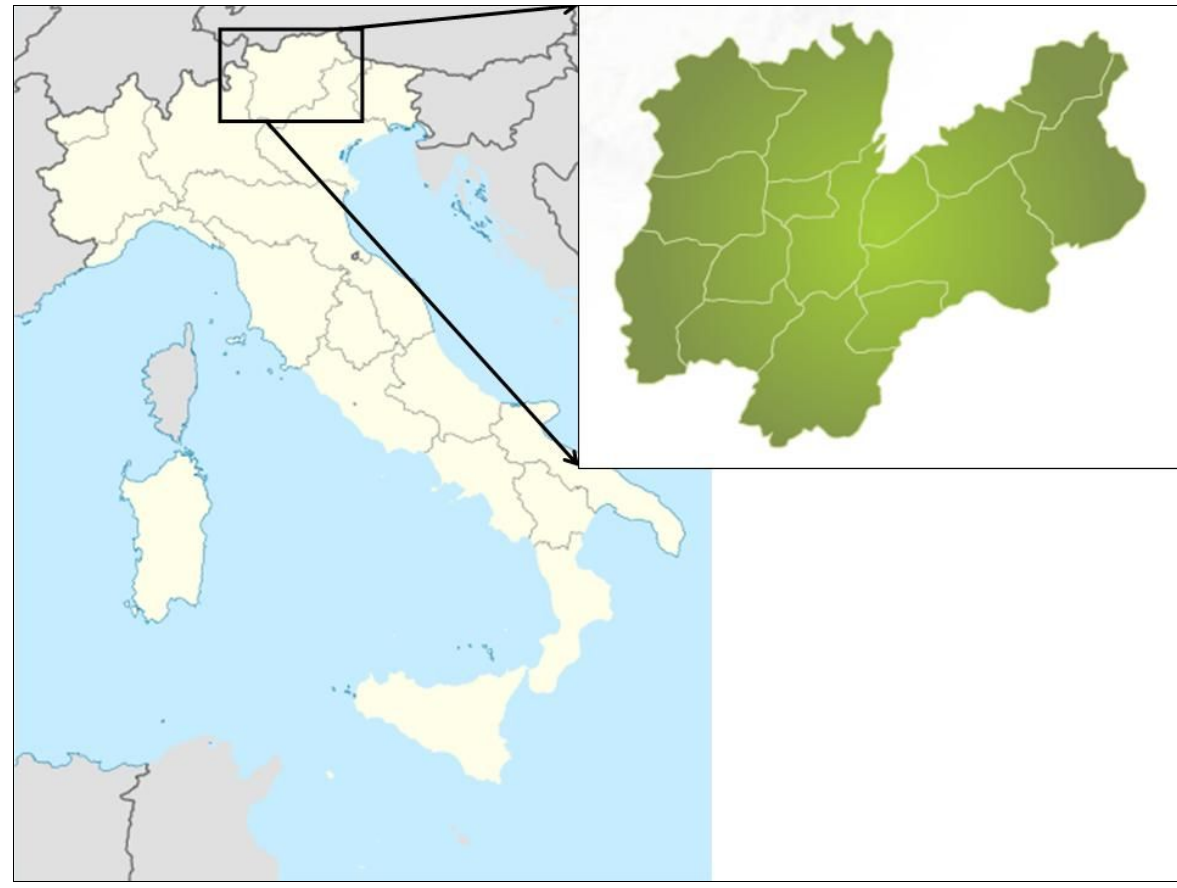

Fig. 1 - Trentino area study in Italy. Source: http://www.visittrentino.it/it/trentino/aree_destinazioni

vices into actual paid goods and public services (i.e., carbon stocking, tourism and recreation in forests, habitat and species conservation, soil and water protection - Gatto et al. 2009, Slee 2011).

This paper discusses the features and peculiarities of forest tourism-recreational innovations as developed in two study areas, in the Auckland Region of New Zealand and

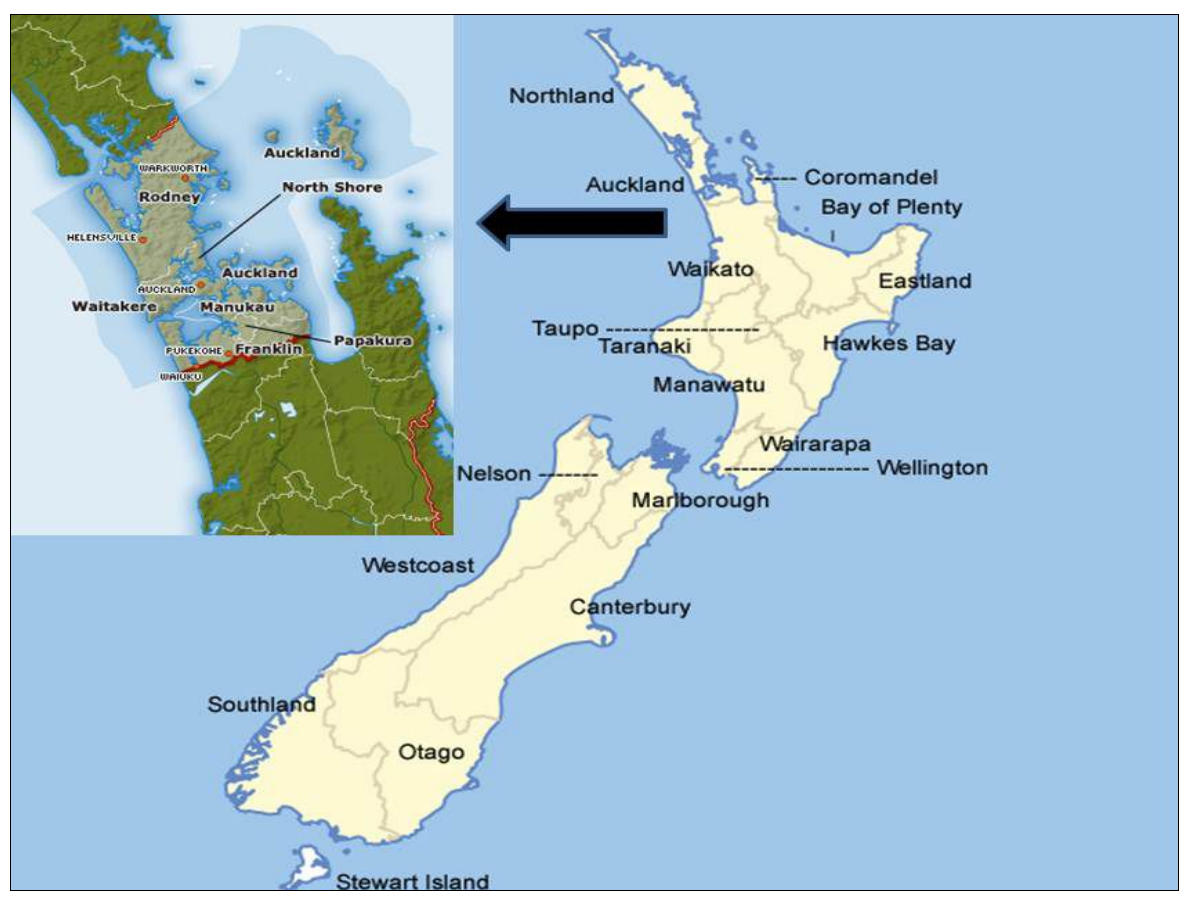

Fig. 2 - Auckland Region area study in New Zealand. Source: http://www.localcouncils.govt.nz
Tab. 1 - Background information on the study areas.

\begin{tabular}{lrr}
\hline \multicolumn{1}{c}{ Parameters } & Trentino & $\begin{array}{c}\text { Auckland } \\
\text { Region }\end{array}$ \\
\hline Total surface (ha) & 620688 & 502380 \\
Forest surface (ha) & 345666 & 199404 \\
$\begin{array}{l}\text { Mountain areas (\%) - } \\
\text { over 1.000 m }\end{array}$ & 70 & 0 \\
$\begin{array}{l}\text { Population (inh.) } \\
\text { Rural population } \\
\text { (inh.) }\end{array}$ & 524826 & 1436500 \\
$\begin{array}{l}\text { Density of population } \\
\text { (inh./km }{ }^{2} \text { ) }\end{array}$ & 39434 & 59300 \\
$\begin{array}{l}\text { Density of rural popu- } \\
\text { lation (inh./km²) }\end{array}$ & 65 & 286 \\
\hline
\end{tabular}

have a positive economic impact for the entrepreneur (in terms of new business development).

\section{Materials and methods}

This study was conducted in the eastern Italian Alps in the province of Trento and in the Auckland Region in the northern part of New Zealand (Fig. 1, Fig. 2, Tab. 1). In Trentino, 56\% of the territory (345 666 ha) is covered by mountain forests, prevalently Picea abies (L.) H. Karst., Larix decidua Mill., Pinus sylvestris L., Fagus sylvatica L., Abies alba Mill. forests, whereas approximately $40 \%$ of the Auckland Region consists of forests (199 404 ha), with a prevalence of Kanuka low forests and shrubland and mixed forests of Metrosideros excels Gaertn., Vitex lucens T. Kirk, Corynocarpus laevigatus J.R. Forst. \& G. Forst., Dysoxylum spectabile G. Forst., Macropiper excelsum G. Forst. and Talipariti elatum (Sw.) Fryxell (Smale et al. 1995). The Auckland Region's climate is primarily a function of its location and regional topography. The average daily temperature during the summer is $23{ }^{\circ} \mathrm{C}$, whereas winter temperatures are $14{ }^{\circ} \mathrm{C}$ on average. The mean annual rainfall varies over areas from less than 1200 to $2200 \mathrm{~mm}$. The Auckland Region is completely flat, with a maximum elevation of $688 \mathrm{~m}$ (Kohukohunui).

The climate of the province of Trento is cool, temperate and mild continental. The mean yearly temperature is $11.5^{\circ} \mathrm{C}$; the average daily temperature in the summer is 21.0 ${ }^{\circ} \mathrm{C}$, whereas winter temperatures are $1.4{ }^{\circ} \mathrm{C}$ on average. The annual rainfall averages 883 $\mathrm{mm}$ with two main peak periods, in spring (May rainfall averages $94 \mathrm{~mm}$ ) and autumn (October rainfall averages $110 \mathrm{~mm}$ ).

To investigate tourism and recreational innovations in the forest, we focused on one category of actors, entrepreneurs/managers, using a non-linear approach. Data were collected using a pretested semi-structured questionnaire. Two samples of Italian and New Zealand entrepreneurs were intervie- 
wed face-to-face by a trained interviewer.

The sampling frame population consisted of entrepreneurs/managers that have introduced forest tourism innovations in recent years. The Trento Chamber of Commerce provided us with a list of names for Trentino. Defining the frame for New Zealand was much more complicated because the Confidentiality Clause in the Statistics Act 1975 does not enable identifying any individual or individual company that provides information to Statistics New Zealand. The sampling frame was thus designed collecting information through the Internet, databases, tourism agencies and expert knowledge. The combination of these different sources of information made us very confident that the sampling frame was appropriate for the population we wanted to study.

After compiling the list of innovations, the population for the two case studies was clustered into three main evident categories: adventure parks, educational farms and cultural attractions. Adventure parks are recreation-oriented parks where visitors can have a fun time engaging in different types of leisure activities, such as suspension courses, cycle-cross, wall-climbing, quad bikes, beach buggies, kayaks, archery, horse trekking, sledging, etc. Adventure parks are more frequently outdoor parks. Educational farms offer services to a wide variety of groups through a large range of activities, such as cultural or scientific programmes and courses linked to farming. In this sense, nature, forests and traditional agricultural activity represent an important innovative development compared to what farms used to be. Cultural and artistic attractions basically consist of art trails and gardens that reflect the trend of enhancing parks and estates with contemporary art in synergy with nature.

From each category of innovation, a random sample was extracted as follows: twelve forest innovations in Trentino (five adventure parks, five educational farms and two cultural attractions), eleven forest innovations in the Auckland Region (four adventure parks, three educational farms and four cultural attractions). The different sample size for each category of innovations in the two case studies reflects the different number of potential innovations of each class in forestry. A preliminary analysis showed that the number of potential innovations in Trentino are approximately one third those in the Auckland Region. The 23 innovations included in the sample are reported in Tab. 2 ; for each of these innovations, we interviewed the entrepreneur.

The questionnaire was arranged in four sections. The first section was designed for investigating the innovator/entrepreneur profile because he/she is the key actor in the in novation process, particularly in its first

Tab. 2 - Sample of forest innovations in Trentino province and the Auckland Region.

\begin{tabular}{|c|c|c|}
\hline $\begin{array}{l}\text { Category of } \\
\text { innovation }\end{array}$ & Trentino & Auckland Region \\
\hline Adventure parks & $\begin{array}{l}\text { Alpine Coaster Gardonè } \\
\text { Busatte Adventure } \\
\text { Piciocaa Adventure Park } \\
\text { Acropark Rio Centa } \\
\text { Forest Park }\end{array}$ & $\begin{array}{l}\text { 4WD Woodhill Park } \\
\text { Tree Adventures } \\
\text { Chaos Paintball } \\
\text { Woodhill Mountain Bike Park }\end{array}$ \\
\hline Educational farms & $\begin{array}{l}\text { Monti e Cielo } \\
\text { Il Favo } \\
\text { Agritur Tenno Bionatura } \\
\text { La Fonte } \\
\text { Malga Riondera }\end{array}$ & $\begin{array}{l}\text { Wild Woozy (Wild on Waiheke) } \\
\text { Coast to Coast Tour (New Zealand Sheep } \\
\text { Farm) } \\
\text { Kiwi Valley Farm Park }\end{array}$ \\
\hline Cultural attractions & $\begin{array}{l}\text { Arte Sella (Sella Art) } \\
\text { Bosco dei Poeti (Poets } \\
\text { forest) }\end{array}$ & $\begin{array}{l}\text { Te Whau Garden } \\
\text { Connels Bay Sculpture Garden } \\
\text { Brick Bay Sculpture Trail } \\
\text { Waitakere Tramline Society }\end{array}$ \\
\hline
\end{tabular}

phases (prior conditions, knowledge and persuasion). Important variables for understanding the potential for the innovation abilities of the entrepreneur are age, gender and risktaking attitude. According to Lunnan et al. (2006), two elements of entrepreneurship have great importance for the success of an innovation: the capability to recognise business opportunities and the aptitude to take calculated risks. We identified these elements by investigating the use of external financial support and the employment of an ex-ante feasibility study before bringing innovation to fruition. The ex-ante feasibility study includes environmental and other consultancies, research about similar installations, business plans, studies about the suitability of the location and its forestry characteristics and visits to other locations where similar innovations are implemented. We expect that a more risk-averse entrepreneur will prefer the use of external financial support and ex-ante feasibility study before implementing the innovation project (Tab. 3 ), even if there are many other variables that may have an influence on risk attitude, such as income, wealth, gender, a second job, etc.

The second section of the questionnaire collected data on the characteristics of the innovation. The origin of innovation, namely the motives that led the entrepreneur to innovate, was investigated through an openended question. With this question, it was possible to identify the impulse for innovation. The impulse for innovation may occur from inside the forest holding (i.e., from entrepreneur, employees, owners or managers), or it can be a business-to-business impulse (i.e., suppliers or other forest entrepreneurs) or an institutional impulse (i.e., forest administration, universities and other research bodies, customers and consumers - Rametsteiner et al. 2005). It is important to investigate this aspect because the strength of the innovation impulse is associated with the probability of success. A set of other questions was designed to investigate the innovation in the local context because the context and conditions under which the forestry sector is operating may not be supportive of innovations. Examples of information collected in this section are the duration of the innovation project, the recreational opportunities provided, and the opening period.

The third part of the questionnaire investigated the economic aspects of innovation, such as start-up and management costs, benefits, employment opportunities and difficulties, and additional important factors influencing the implementation of the innovation project. Costs and benefits were evaluated using a rank-ordered format, enabling us to identify the largest initial costs and most profitable market segments. A 5-point Likert (1932) scale was used to investigate the difficulties and important factors affecting the implementation of innovations (i.e., fulfilment of the project, mobilisation of funding, passion for the activity and sharing of the background mission, motivated staff, etc). The mean and standard deviation of each indicator were estimated, and significant differences between Trentino and Auckland Region were investigated by applying the Mann-Whitney U non-parametric test. The last question of this section analysed the employment opportunities derived from the innovation. The fourth section collected data for the identification of visitors' features and marketing policies including the monitoring of customer satisfaction. Data were statisti-

Tab. 3 - Type of entrepreneur with regard to risk attitude.

\begin{tabular}{|c|c|c|}
\hline $\begin{array}{c}\text { Type of } \\
\text { entrepreneur }\end{array}$ & $\begin{array}{c}\text { External } \\
\text { financial } \\
\text { support }\end{array}$ & $\begin{array}{c}\text { Ex-ante } \\
\text { feasibility } \\
\text { study }\end{array}$ \\
\hline Risk-lover & No & No \\
\hline Moderate risk-lover & Yes/No & $\mathrm{No} / \mathrm{Yes}$ \\
\hline Risk-averse & Yes & Yes \\
\hline
\end{tabular}


cally analysed by XLStat (Anonymous 2012) and summarised in a single scenario with the final purpose of evaluating the strengths, weaknesses, opportunities, and threats (S.W.O.T. analysis) of the forest innovations in the Auckland Region (New Zealand) and Trentino (Italy).

\section{Results and discussion}

The results of the 23 interviews (12 in Trentino and 11 in the Auckland Region) will be presented focusing on innovator/entrepreneur characteristics, innovation characteristics and economic aspects. A final elaboration will sum all the results through a S.W.O.T. analysis, which also include marketing policies.

\section{Entrepreneur characteristics}

The results about the characteristics of innovator/entrepreneur revealed interesting differences between the two case studies. Trentino registered a younger range of innovators, namely a peak of entrepreneurs or managers who were between 20 and 50 years old $(91.6 \%)$, whereas the remaining $8.3 \%$ were over 50 years old. Instead, the New Zealand ranged from $30-50(38 \%)$ to over 50 years old $(45.5 \%)$. This appears to have some positive return for Trentino, which appears to have younger managers that may potentially be more dynamic and more inclined to flexibility in today's highly variable market. On the other hand, the Auckland Region may have more experts and proficient people who are more experienced in the business and market.

Another important difference between the two case studies concerned the gender of the innovator. Whereas in Trentino males were prevalent ( $73 \%$ male, $27 \%$ female), the Auckland Region presented some sort of balance between sexes $(56 \%$ male and $44 \%$ female).

The next major difference between the two areas was the importance of external financial support in the start-up phase. The mindset and the risk-taking attitudes of the innovator influence the start-up activities and play a key role in the continuation of the innovation process. Normally, external financial support in the first phases of the innovation process reduces the risk of the entrepreneur, but in the long run, the constan availability of external funds indirectly influences his/her mind-set. In New Zealand, financial sources needed for the initial investment were primarily provided by the entrepreneurs $(80 \%)$, whereas the remaining $20 \%$ were bank loans, which represented over $50 \%$ of the total amount. Vice versa, in Trentino, $58.3 \%$ of the entrepreneurs received external financial support, consisting of local grants $(62.5 \%$ of external funds) or European grants $(25 \%)$ and bank loans $(12.5 \%)$. The use of an ex-ante feasibility study is another important indicator of risk aversion. In Trentino, entrepreneurs made use of this tool $-41.7 \%$ of respondents implemented a feasibility study - more often than in the Auckland Region, where only $18.2 \%$ of respondents performed this type of analysis.

Reading these two indicators together allowed us to classify respondents into types of entrepreneurs according to Tab. 3. The result is remarkable. In Trentino, only $25 \%$ of respondents were risk-lovers, whereas $50 \%$ were moderate risk lovers. However, in the Auckland Region, $70 \%$ of respondents were risk-lovers, and $20 \%$ were moderate risk lovers.

\section{Innovation characteristics}

The origin of innovation was investigated separately for the three previously identified categories of innovations. The open-ended format of the question did not allow precise encoding, but the results showed for both contexts a prevalence of internal impulses, such as passion and knowledge of the sector and the experience of the entrepreneur, friends or other members of the family in the field. In support of this finding, in the European context, the internal impulses represent the most important driving force, with a percentage ranging from a minimum of $20 \%$ to a maximum of $90 \%$ of the total (Rametsteiner et al. 2005). The full variety of reasons connected to the implementation of the examined innovations is completed by the imitation of international sites, where similar innovations are implemented, strong beliefs and external suggestions from other economic actors. Tab. 4 reports answers from respondents.

The offered activities were investigated with an open-ended question aimed at identifying the core business. Trentino showed a specialisation in two main types of attractions, forest adventure parks and educational farms. Forest adventure parks are built in the forest with eco-compatible materials. They offer acrobatic ropes trails suspended between trees. Artificial obstacles made from ropes, nets and wood represent the acrobatic elements. In forest parks, children, adults and families can have fun in the open air. Educational farms are the most widespread enterprises of this type in Trentino and offer a typical example of learning by performing concept implementation. They offer services to schools and families. However, Trentino records only two isolated cases of cultural and artistic attractions. The first is an international exposition organizing cultural events of contemporary art in the forest; the second one is a walk-able trail in the forest where poems and paintings from international and Italian artists are displayed.

In contrast, in the Auckland Region, there is a wider diversification of innovative tou- rism-recreational attractions. Adventure parks indeed offer several types of activities. There are forest parks (acrobatic trails with artificial obstacles), paintball fields (areas where players can play paintball), Jeep forest parks (places that enable 4WD owners to experience the thrill of driving off-road on forest trails), and bike parks (places to experience adventure trails tailored for mountain bikes), among which the most popular are paintball fields. Cultural attractions include art and poetry expositions, as for Trentino but with a wider distribution both in terms of quantity and variety (art expositions, sculpture trails and gardens and educational tramline in the rainforest). Educational farms are more team-building oriented, providing more structured services, such as archery, laser clay bird shooting, team strategy activities and tours.

There is also a difference in the duration of the innovation project between the two study areas. The Auckland Region began implementing tourism-recreational activities in the forest less than a few years earlier than Trentino. The total average was, respectively 6.65 years compared to Trentino with 5.36 years. Adventure parks are a more recent phenomenon in Trentino, having existed 3.40 years against 6.38 for Auckland. This finding implies relatively limited experience among managers. Meanwhile, in the Auckland Region, entrepreneurial attitudes have been more highly experimented with. It may be a matter of a better business context or a higher risk-taking attitude of New Zealand managers. This difference did not manifest in educational farms. The phenomenon appears to be born simultaneously in the two areas; in fact, we observed an average of 5.60 years in Trentino and 6.00 years in the Auckland Region. Finally, for both contexts, the cultural and artistic activities were the oldest compared to the full sample (20 years in Trentino and 15 years in the Auckland Region).

All of these tourism-recreational activities in Trentino had a marked seasonality, with June to September being the predominant season. However, the interval was variable and ranged from a minimum of three to nine months. Whereas $91 \%$ of the Auckland Region's respondents reported being open for the entire year, this figure is only $25 \%$ in Trentino. Indeed, the Auckland Region enjoys a warm coastal climate without extremes of temperature and is one of the sunniest spots in the country, which allows almost all the tourism-recreational attractions to be open all year long, whereas the unfavourable climatic conditions of winter in Trentino prevent the opening of businesses in this season.

\section{Economic aspects}

Items for construction and start-up costs 
were fairly similar between the two samples (Fig. 3). The most important costs in Trentino were materials and structure $(23.1 \%)$ and the initial staff training (20.5\%), whereas in the Auckland Region, the most prominent costs were those of licences and permits (25\%), consulting $(19.4 \%)$ and materials and structure (19.4\%). Sorting data by category of innovation, representing the main cost in Trentino for adventure parks were initial staff training and licences/permits, whereas in the Auckland Region, for the same category it was represented by consulting and licences/permits The initial costs for educational farms were in both areas lower than for the other categories.
Moreover, it is interesting how the segmentation of the market is concentrated in two categories in Trentino ("families" and "school classes"), whereas in the Auckland Region, it is more evenly distributed ("adults over 35 years", "families", "young" and "other"). The considerable extent of the category "other" (Fig. 4) required further investigation, leading to the existence of another consistent segment: corporate clients, which are essentially business people whose reasons for travelling are connected to work. This cluster appeared to be exclusive to the Auckland Region, due to the implementation of a special type of activity: team-building activities. These activities consist of recreational situations that provide an educational opportunity for participants, enabling them to get to know each other better and recognise where the strengths of different team members lie. Such activities help them to appreciate that more can be achieved as a team than as an individual. Having fun together is one of the best ways to build camaraderie and a shared mission, which is why this initiative can be very effectively pursued in an environment such as that offered by adventure parks. In a professional context, teambuilding can help management staff to understand the attributes and skills that people in their staff have that is not necessarily evident in their normal work routines. Leadership and organisational skills are often highlighted, as are lateral and creative-thin-

Tab. 4 - Origin of the idea underlying the innovation.

\begin{tabular}{|c|c|c|}
\hline Region & Adventure Parks & Educational Farms \\
\hline Trentino & $\begin{array}{l}\text { Similar innovation abroad: } \\
\text { One manager of the Association of Cableways } \\
\text { developed the concept of the attraction. The } \\
\text { goal was to increase tourist inflow during } \\
\text { summer. Several inspections were made in a } \\
\text { neighbouring country to analyse establishments } \\
\text { already operating. } \\
\text { The financial backer saw the adventure parks } \\
\text { abroad. } \\
\text { Experience in the field: the triggering event was } \\
\text { the meeting with the person who had worked in } \\
\text { the first Italian adventure park and wanted to } \\
\text { create one in his home territory. The two founding } \\
\text { brothers are now charter members of this new park. } \\
\text { Passion and knowledge of the sector: the idea } \\
\text { originated from the keenness for children and an } \\
\text { interest in local development. The founders of } \\
\text { the attraction are two brothers. One of them is an } \\
\text { alpine guide, who had heard much about these } \\
\text { attractions from mountain guides. }\end{array}$ & $\begin{array}{l}\text { Belief in the philosophy: } \\
\text { The idea came from the continuous } \\
\text { involvement of the family in social } \\
\text { initiatives; the underlying goal is to } \\
\text { spread the organic and biodynamic } \\
\text { philosophy with the "social farm" } \\
\text { as the eventual aim. } \\
\text { The driving force was the will to } \\
\text { diffuse the organic lifestyle as a } \\
\text { natural means of living. } \\
\text { The project began in collaboration } \\
\text { with the "Steineriana School" and } \\
\text { was continued due to the passion } \\
\text { for the activity. } \\
\text { Added value: the farmer would like to } \\
\text { supplement income. } \\
\text { Passion and knowledge of the sector: } \\
\text { important elements were professional } \\
\text { proficiencies, innovative ideas and the } \\
\text { property on which the facilities sit. }\end{array}$ \\
\hline
\end{tabular}

External suggestion: a supplier of specialised equipment suggested the implementation of the initiative for diversifying supply and extending the tourist season.

Auckland Exclusivity: the manager was driven by the region specific suitability of the land and the possibility of being the first in the region to construct an adventure park.

Passion and knowledge of the sector:

The innovator began climbing trees when he was young; with playmates, they used to have their own field at a friend's house and began to organise birthday parties and such events, which eventually turned into a commercial enterprise.

There was a need to manage and control the mountain biking recreation activity occurring in the local forest.

Similar innovation abroad: the manager experienced the French innovation of adventure parks dating back to the 1990s.

\section{Artistics and cultural} attractions

Passion and knowledge of the sector:

Three local artists decided to pool their experience, knowledge and assets to set up an international exposition.

The entrepreneur's passion for art and poetry. He owned property suitable for being turned into a cultural park.

\begin{abstract}
Passion and knowledge of the sector: One of the managers had a background in outdoor training and team-building education. She designed a fun team event attraction that includes activities (i.e., archery, laser clay bird shooting and team tactics) planned in a round-robin style.

Added value and belief: the desire to offer something extra in addition to holiday farm stays, made the owners travel around to learn and implement what an actual eco-tour is.
\end{abstract}

Passion and knowledge of the sector: Passion for art was turned into an artistic park, a "gallery without walls", where the environment is a coastal property with native plants.

The owners love native arts. They set up the artistic park to support New Zealand sculpture art. 


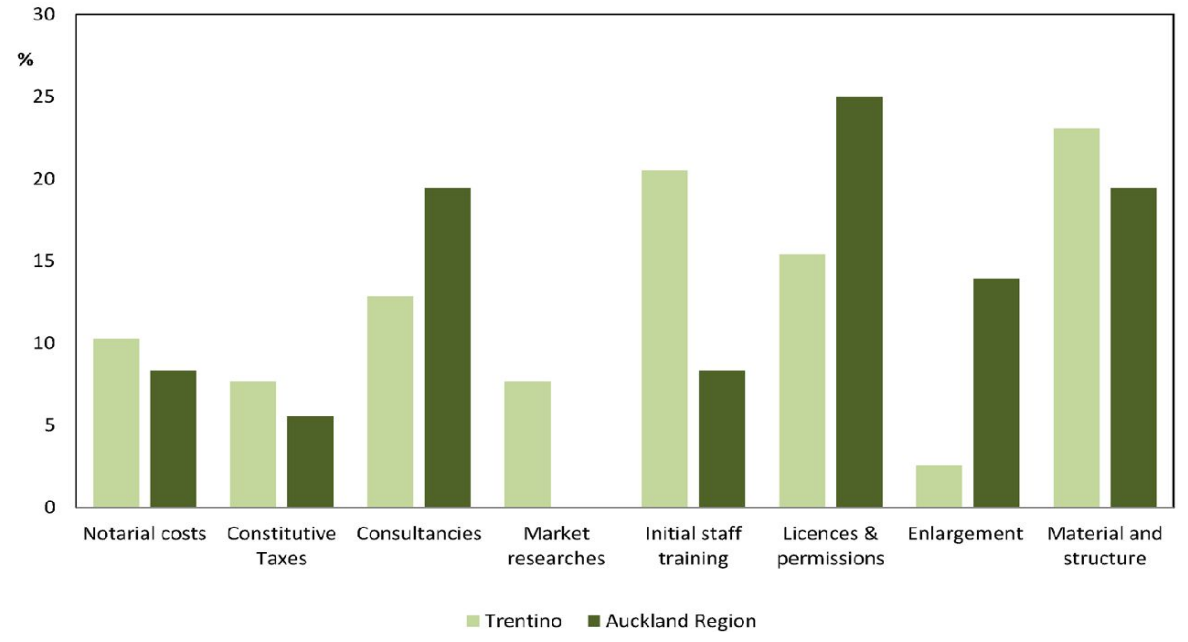

Fig. 3 - Distribution of construction and start-up costs in Trentino and Auckland Region (full samples).

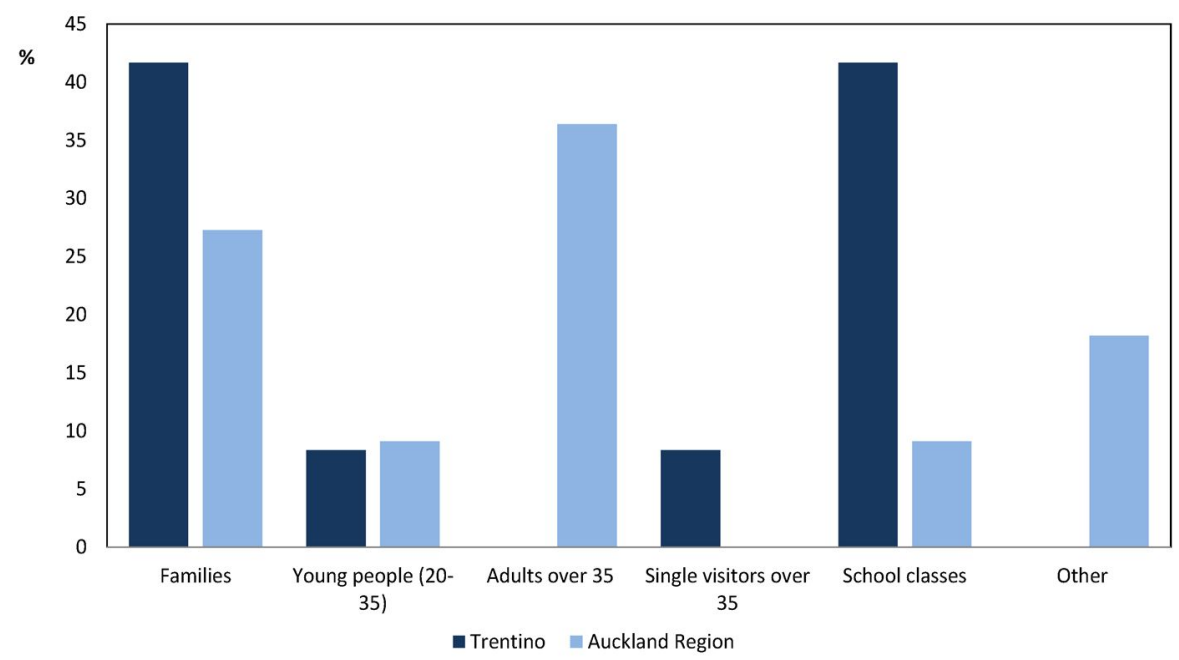

Fig. 4 - Most profitable market segments in Trentino and Auckland Region.

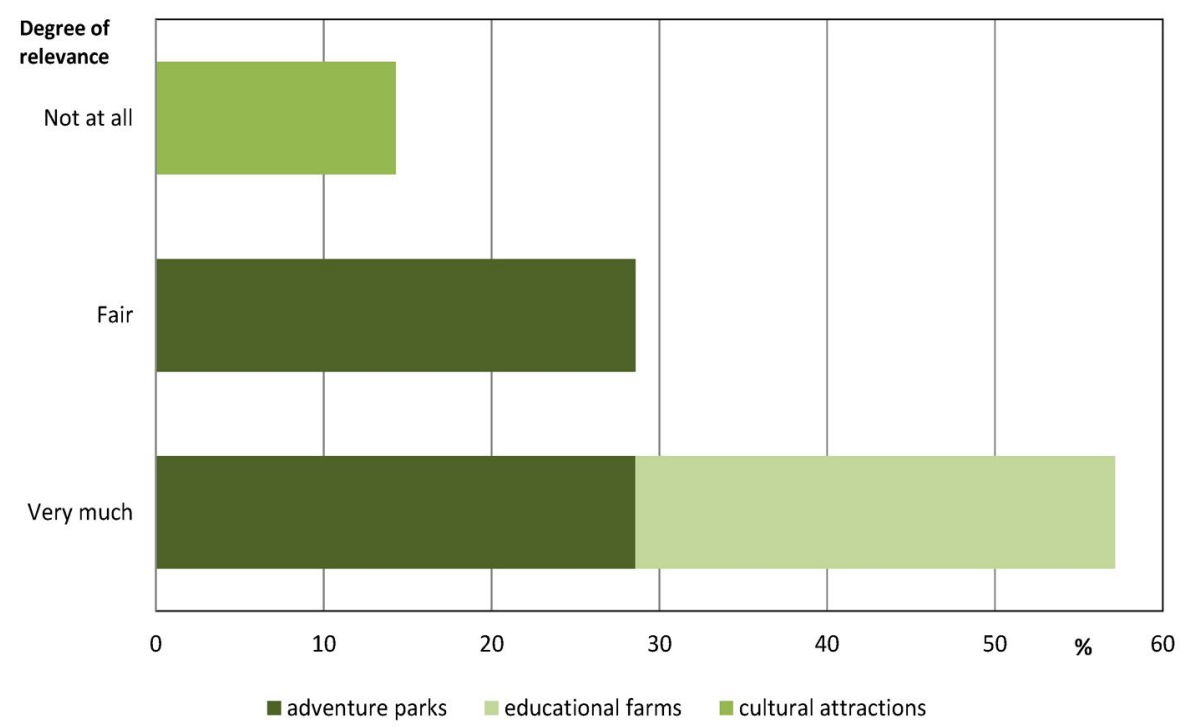

Fig. 5 - Relevance of team building and outdoor training (Auckland Region). king skills. The development of these initiatives has great potential, and an outdoor adventure location appears to have great success within this scope. Previous experiences in the Auckland Region include Chaos Paintball in the forest White Acres located near Northshore, and Wild Woozey in Vineyard island, where several activities are planned in a round-robin style - archery and laser clay pigeon shooting and team strategy activities.

Indeed, Fig. 5 shows that adventure parks are likely to exploit the opportunity offered by these activities. New Zealand respondents witnessed a "fair" and "very much" relevant function held by this business area; $57 \%$ is the rate for adventure parks; educational farms follow, with almost $29 \%$ stating that this business area plays a very important role.

Interesting results were obtained by comparing the fostering and impeding factors in the implementation of innovation in the two contexts. In Trentino, the fulfilment of the project was rated as being the most significant problem, followed by the difficulty of drowning tourists and raising start-up financing. On the other hand, entrepreneurs in the Auckland Region indicated advertising the attraction to be the most difficult aspect. The fulfilment of the project and the drowning of tourists were other relevant difficulties. The common denominator between the two samples was the low mean, which is never higher than 1.64 (Tab. 5). If impeding factors are divided into macro groups (economic, legislative, social, and technical-organisational), in New Zealand, the most important were the technical-organisational factors (fulfilment of the project and advertisement of the attraction), whereas in Trentino, the most important were both economic and technical-organisational factors (raising start-up financing and fulfilling the project). This result confirms recent literature showing that in different areas of Europe, the most important factors are, first, economic factors and, second, legislative ones (Rametsteiner et al. 2005, Làskovà \& Posavec 2011).

Entrepreneurs in Trentino and in the Auckland Region appeared to attach importance to the same fostering factors in the implementation of the innovation. It is worth noting that neither of them identified earning expectations in the top position. It rather appears to be a matter of a strong motivational driving force. In any case, it would appear that this factor weighs more in Auckland that in Trentino, with the mean being 1.90 (st. dev. $=1.45$ ) in New Zealand and 1.55 (st. dev. $=1.04$ ) in Italy (Tab. 6). This value may indicate a more marked entrepreneurial attitude within that region, confirming our first hypothesis. For each context, the professional motivation of the entrepreneur and staff 
was considered the most important fostering factor in the implementation of the innovation, while other studies place greater emphasis on economic and institutional support (Rametsteiner et al. 2005, Làskovà \& Posavec 2011). The Mann-Whitney U nonparametric test showed no statistically significant differences between Trentino and the Auckland Region.

Employment opportunities are much more limited in Trentino than in the Auckland Region, where the numbers are over double for both permanent and seasonal workers (Tab. 7). Moreover, $45 \%$ of the workers in the Auckland Region but only $34 \%$ in Trentino were permanent. Interestingly, $66.7 \%$ of Italian respondents had a second job. This phenomenon is certainly due to the mentioned seasonality of these outdoor activities in Trentino. The corresponding rate for Auckland Region is $44.4 \%$, which is also significant. Also noteworthy is the high frequency $(55.6 \%)$ of students employed in these innovative-recreational attractions in the New Zealand region.

\section{S.W.O.T. analysis}

With SWOT analysis, we provide an overview of strengths, weaknesses, opportunities and threats characterising the internal and external environment of the examined tourism innovations in the forest. We implemented the SWOT analysis to identify developing opportunities for this innovative forest sub-sector, focusing mainly on the transferability of innovation between the two contexts. Our focus is on the two innovative enterprise systems.

The exploding success of tourism-recreational activities in the forest in Trentino and the increasing demand for nature gives these attractions an advantage in the tourism sector (Fig. 6). Indeed, young managers could exploit information technology to maximise the costless opportunity of social networks, community and visibility online for promotional or commercial purposes. Specifically, educational farms present a weak market image that could be overcome by using these effective and efficient tools (e.g., newsletters, Facebook, Tripadvisor, Twitter, Linkedin., etc.). As a general suggestion for marketing, there is also the great opportunity represented by the proximity of the Dolomites, which were recently included in the UNESCO World Heritage List. Advertisement or educational programmes covering this topic could help to drive success. These innovative attractions offer challenging situations in the forest that meet the increasing demand for nature, especially for characterand team-building experience. This is an emerging issue that is especially interesting for corporate clients, which represent a market segment that has not yet been captured by Trentino. Developing such activities
Tab. 5 - Mean and standard deviation for each impeding factor in the implementation of innovation (5-point Likert scale).

\begin{tabular}{lcccc}
\hline \multirow{2}{*}{ Factors } & \multicolumn{2}{c}{ Trentino province } & \multicolumn{2}{c}{ Auckland Region } \\
\cline { 2 - 5 } & Mean & St. dev. & Mean & St. dev. \\
\hline $\begin{array}{l}\text { Fulfilment of the } \\
\text { project }\end{array}$ & 1.64 & 1.12 & 1.18 & 0.60 \\
$\begin{array}{l}\text { Raise start-up } \\
\text { financing }\end{array}$ & 1.36 & 1.29 & 1.08 & 1.08 \\
$\begin{array}{l}\text { Attract visitors } \\
\begin{array}{l}\text { Advertise the } \\
\text { attraction }\end{array}\end{array}$ & 1.36 & 0.92 & 1.18 & 0.75 \\
$\begin{array}{l}\text { Differentiate the } \\
\text { offer }\end{array}$ & 0.73 & 0.83 & 1.64 & 1.12 \\
\end{tabular}

offer

Other influencing Acceptance by the local community; Exogenous influences, such as factors licences and permits; creation of a petrol price, etc.; legislation and company reputation and image; bureaucracy; converting a perceived limited financial resources of the free-riding area into a pay-to-ride school. venue.

Tab. 6 - Mean and standard deviation for each fostering factor in the implementation of innovation (5-point Likert scale).

\begin{tabular}{|c|c|c|c|c|}
\hline \multirow{2}{*}{ Factors } & \multicolumn{2}{|c|}{ Trentino province } & \multicolumn{2}{|c|}{ Auckland Region } \\
\hline & Mean & St.dev. & Mean & St.dev. \\
\hline $\begin{array}{l}\text { Passion for the } \\
\text { business and sha- } \\
\text { ring of the back- } \\
\text { ground mission }\end{array}$ & 3.55 & 0.69 & 3.73 & 0.47 \\
\hline Motivated staff & 3.45 & 0.69 & 3.18 & 1.17 \\
\hline $\begin{array}{l}\text { Qualified or } \\
\text { experienced } \\
\text { personnel }\end{array}$ & 2.64 & 1.03 & 2.36 & 1.29 \\
\hline $\begin{array}{l}\text { Good earning } \\
\text { expectations }\end{array}$ & 1.55 & 1.04 & 1.90 & 1.45 \\
\hline Low start-up costs & 1.09 & 1.58 & 1.80 & 1.35 \\
\hline $\begin{array}{l}\text { Other influencing } \\
\text { factors }\end{array}$ & \multicolumn{2}{|c|}{$\begin{array}{l}\text { Strategic position; constant upda- } \\
\text { ting with national and international } \\
\text { competitors; determination and } \\
\text { willpower; mutual collaboration } \\
\text { philosophy. }\end{array}$} & \multicolumn{2}{|c|}{$\begin{array}{l}\text { Other know-how/personal } \\
\text { experience in the field. }\end{array}$} \\
\hline
\end{tabular}

would enable a broadening of the customer base. Another interesting prospect is represented by new successful examples in the international context, such as paintball fields and bike parks. Further opportunities provided by tourism-recreational innovations would involve the local community not only to achieve new (potentially) loyal customers but also to create collaborations among territorial enterprises. Such a network could develop a more structured offer addressing the process towards a comprehensive destination management. Moreover, Customer Relationship Management (CRM) may represent a good solution for overcoming one of the weaknesses related to feedback assessment and managing long-lasting relationships with clients (Chen \& Popovich 2003). Structuring feedback to enable systematic collection could generate a beneficial virtuous cycle. Whereas young managers represent a strength for this sector, the lack of female entrepreneurship remains a weakness. Female incentives, an issue that only local administration can address, could help to fill this gap.

All of these suggestions represent possible challenges for the management to work on,
Tab. 7 - Overview of workers placed per enterprise.

\begin{tabular}{lcccc}
\hline \multirow{2}{*}{ Area } & \multicolumn{2}{c}{ Permanent workers } & \multicolumn{2}{c}{ Seasonal workers } \\
\cline { 2 - 5 } & Total number & Mean & Total number & Mean \\
\hline Trentino province & 15 & 2.14 & 29 & 4.14 \\
Auckland region & 32 & 3.56 & 41 & 8.20 \\
\hline
\end{tabular}



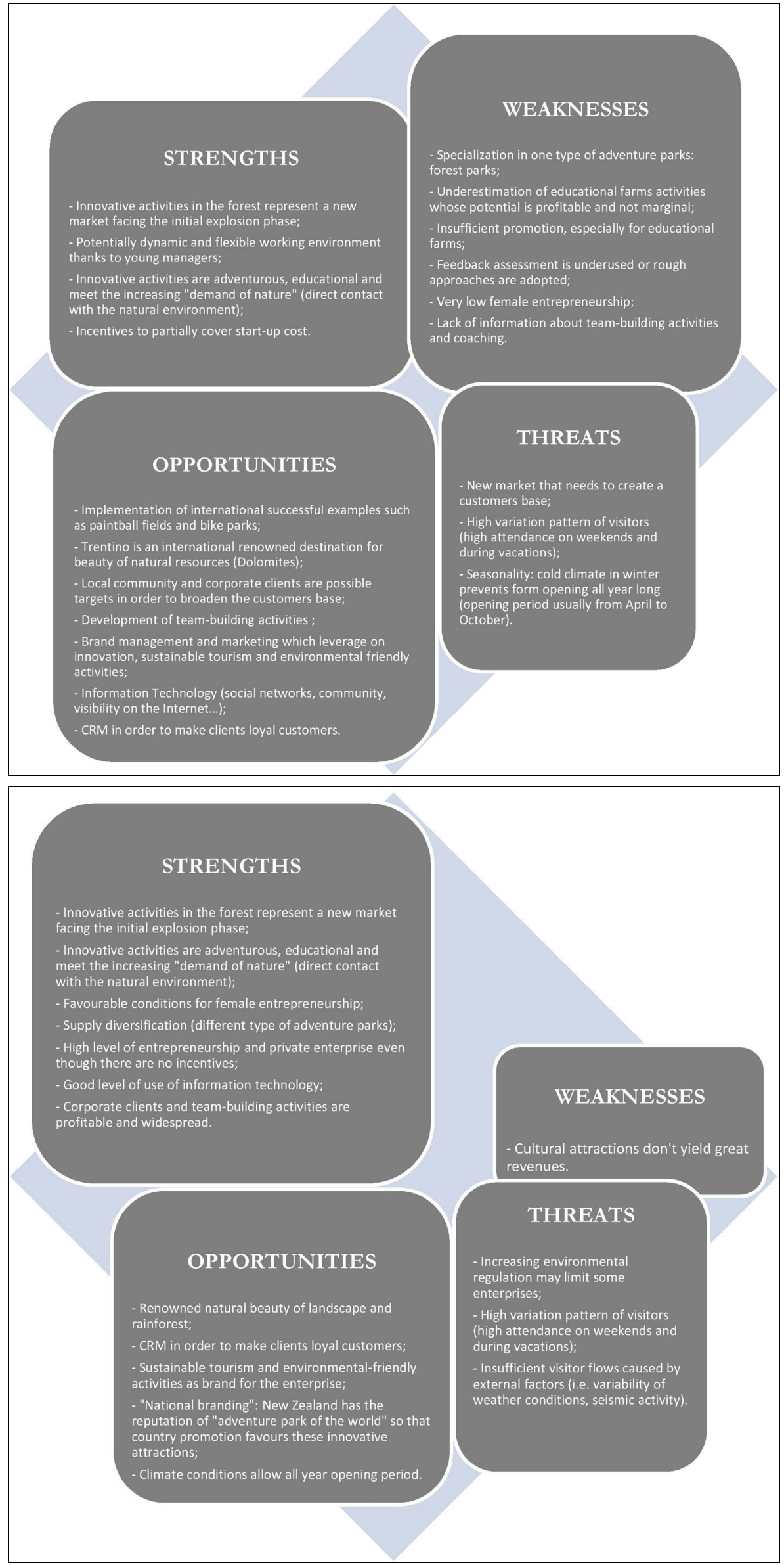

Fig. 6 - S.W.O.T. analysis for tourism-recreational innovations in Trentino.

Fig. 7 - S.W.O.T. analysis for tourism-recreational innovations in the Auckland Region. 
but there are some other threats caused by external factors that are more difficult to address. The two regions differ in some important structural characteristics. The main external factor is that Trentino has an ancient history of human settlement since the EarlyMiddle Bronze Age and Iron Age, whereas the Auckland Region was settled in approximately 1350 by the Maori and approximately 1850 by Europeans. Consequently, the two study areas have different degrees of urbanisation: $90 \%$ of Aucklanders live in urban areas, whereas the rural population is $4.1 \%$ of the total; on the contrary, in Trentino, approximately $75 \%$ of the population lives in rural areas. The population density is very high in the Auckland metropolitan area, where approximately 1380000 inhabitants live, whereas in the rural land area, the population density is approximately 36 inh. $\mathrm{km}^{-2}$. In Trentino, the population density is 84.5 inh. $\mathrm{km}^{-2}$, which drops to 64 inh. $\mathrm{km}^{-2}$ in rural areas. Another importan difference is the elevation of the land Whereas in Trentino, $70 \%$ of the total land area is mountainous (over $1000 \mathrm{~m}$ ), the highest elevation is only $688 \mathrm{~m}$ slm in the Auckland Region. One more external factor is that in Trentino, the cold climate in winter prohibits year-round activities. These external factors mean that in Trentino, the environmental and the socio-cultural resistance to innovation may be higher in comparison with a more urbanised and more recently inhabited area such as the Auckland Region.

In the Auckland Region (Fig. 7), strengths appear to prevail over any other aspect; indeed, what has emerged is that entrepreneurship appears evenly spread among men and women and that managerial and risk-taking attitudes reach a high level. Attention to and demand for tourism-recreational products and services in the forest are growing, enhanced by "country branding". Diversification and a good level of experimentation of various types of adventure parks represent a further positive feature, but, on the other hand, increasing environmental legislation is threatening it. In fact, attractions such as Jeep forest parks risk being banned for not being environmentally sustainable; therefore, some alternative solution may be determined. A further strength consists of the great success achieved by developing teambuilding activities and outdoor training, which has also made possible the penetration of the corporate clients segment, which could be managed with CRM to manage relationships (team-building packages tailored for specific business projects, news-letter according to the client's area of interest) and get the most out of them.

Cultural attractions appear to have some profitability problems. This situation could be improved by implementing some awareness campaign about art and tramline in the rainforest, branding them as attractions that are respectful of natural equilibria and part of environmentally friendly activities. Promotion may be managed by marketing the cultural attractions as the "alternative experience" compared to the usual adventurous holiday typical for the country. Engaging in brand management could help to overcome this weakness.

New Zealand's natural environment is renowned for its beauty, with its charming landscape, luxurious rainforest and even temperate climate, and its environmental diversity favours an abundance of activities all year round. However, the region presents some factors that are more difficult to overcome or manage, such as those shown inside the threats quadrant, namely the seismic condition of the country, which may represent an external problem to consider carefully when starting an enterprise.

\section{Conclusions}

Innovation systems of traditional sectors, such as the forestry sector, are limited in terms of the demand for new products (Kubezko et al. 2006), whereas the social demand for environmental services in industrialised countries is growing. To a certain extent, the forest sector has been able to meet this new demand by developing new ideas. In general, innovation represents the driving force for differentiation and competitiveness within the service sector of forestry, as noted by Redford \& Adams (2009), Farley \& Costanza (2010), and Notaro et al. (2006), and it occurs at the moment when forest owners are able to enhance the value of their property and, consequently, the services it offers, turning them into added value and a source of remuneration for the invested labour and capital. Accordingly, the transformation of forest recreational services into actual paid public services represents an innovation. In particular, some forest services are now marketed through established market values in well-functioning markets. These services can be categorised into adventure parks, educational farms and cultural attractions in forests. These types of innovation have been implemented throughout the world but with different traits depending on the specific context. To contribute to the detection of the peculiarities and the identification of developing opportunities through the transferability of innovations, we analysed two case studies located poles apart: the Auckland Region in New Zealand and Trentino in Italy.

Trentino has an important potential to develop that has currently not yet been realised or sufficiently experimented with. The focus on a limited variety of attractions could be overcome, in light of the example of international contexts, such as the Auckland Region. Some types of enterprises indeed ap- peared imitable from the New Zealand context: paintball fields, forest tramline and mountain bike parks. Further inspirational cues include the fully developed offerings (i.e., packages offering accommodation, outdoor and team building activities, restaurant and tours) observed in the Auckland Region, which represent the creation of an integrated and complex product that is desirable for different targets. In particular, the segment of "corporate clients" does not exist in Trentino. These customers are extremely important because they may have a significant spending capacity and are attracted by the fully developed offerings provided in New Zealand farms and team-building activities and events. We believe that the structural characteristics mentioned above, in terms of the history of human settlement, population concentration and the presence of mountain land, may have an effect on the number of attractions implemented in Trentino but not on the realisation of the new ideas themselves. Moreover, entrepreneurs in Trentino can also exploit the fact that this province continues to attract a great number of summer tourists, partially compensating the thin demand from urban areas compared to the Auckland Region. Therefore, this study could represent a valuable action aimed at increasing awareness of tourism-recreational managers and forest holders in Trentino of keeping up with international sectoral innovations. Dedication to such activities should be faced by keeping an eye wide open towards new initiatives implemented elsewhere and by listening to customers as a resource for constant adjustment to the market change. As Rametsteiner \& Weiss (2006b) assert, the valorisation of the territory by exploiting business opportunities in marginal areas, and the value generated therein, could fill the gap between rural or mountain locations and more urbanised places. Policies promoting innovation as well as entrepreneurship can assist this process.

In the Auckland Region, the implementation of these innovations proved to be more convincing. Entrepreneurs have been able to better exploit the demand for environmental services offering a wider variety of innovative recreational activities. However, the implementation of new environmental regulations may prohibit attractions that have a great impact on the natural environment (i.e., Jeep forest parks); therefore, the New Zealand region must gear innovations towards more environmentally sustainable solutions. In this regard, entrepreneurs from the Auckland Region could implement attractions on a smaller scale, following the Trentino example. An untapped opportunity in both the Auckland Region and Trentino is the monitoring of and marketing to visitors. Related outcomes suggest increased structuring of the final phase of client relationships to 
extract the most value from them. Feedback assessment and awareness in the context of long-lasting relationships would activate a virtuous cycle for continuous improvement The best tool for implementing this approach would be to optimising the costless opportunities provided by social networks, online communities, and general online visibility.

Niskanen et al. (2007) describe the direction currently followed by the forest sector as attempting to deliver multifunctional benefits of the farm and forest structures. Alongside the policy changes, the pressure on agriculture and other primary industries has required a search for new market opportunities that are often connected to leisure demands. However, it is a reality that those who own the rural resources may be geographically well placed to offer these new services but may lack the commercial skills and entrepreneurial values to initiate them (Niskanen et al. 2007). This gap must be filled, but this may require some time. So far, the ability and willingness of forest owners and managers to recognise changes, to make better use of arising opportunities and to introduce innovations in their forest holdings shows an increasing and profitable dimension that has bright prospects. The fertile ground confirmed by the success already achieved by tourism-recreational innovations in the forest, both in the Auckland Region and in Trentino, and the support of a strong entrepreneurial motivation foresees bright prospects for these innovations. Comparing and imitating best practices of sustainable management of local forests would also contribute to the process of raising consciousness on environmental issues spreading so the positive behaviour towards natural resources. No other environmental sensitisation action would work better than experiencing nature. The development process is facing a more advanced phase in the Auckland Region, but potential can be clearly exploited further on even in Trentino by using proper inputs.

\section{References}

Anonymous (2012). XLSTAT Getting started manual. Addinsoft. [online] URL: http://www.xlstat.com/uploads/video/getting-started/xlstat-getting-started-manual.pdf

Chen IJ, Popovich K (2003). Understanding customer relationship management (CRM): People, process and technology. Business Process Management Journal 5: 672-688. - doi: 10.1108/ 14637150310496758
Duduman G, Bouriaud L (2007). Managing innovations in wood harvesting and primary processing firms - case study of Suceava. Forestry Studies 46: 89-101. [online] URL: http://mivana. emu.ee/orb.aw/class=file/action=preview $/ \mathrm{id}=355$ 217/FS MU 46 089-101.pdf

Edquist $\bar{C}$ (1997). Systems of Innovation: Technologies, Institutions and Organizations. Pinter/ Cassell, London, UK.

Edquist C, Johnson B (1997). Institutions and organisations in systems of innovation. In: "Systems of Innovation: Technologies, Institutions and Organizations" (Edquist C ed). Pinter/Cassell Academic, London, UK and Washington, USA.

Farley J, Costanza R (2010). Payments for ecosystem services: from local to global. Ecological Economics 11: 2060-2068. - doi: 10.1016/j.ecolecon.2010.06.010

Gatto P, Pettenella D, Secco L (2009). Payments for forest environmental services: organisational models and related experiences in Italy. iForest 2: 133-139. - doi: 10.3832/ifor0504-002

Kline SJ, Rosenberg N (1986). An overview of innovation. In: "The positive sum strategy: harnessing technology for economic growth" (Landau R, Rosenberg N eds). National Academic Press, Washington,USA, pp. 275-305.

Kubezko K, Rametsteiner E, Weiss E (2006). The role of sectoral and regional innovation systems in supporting innovations in forestry. Forest Policy and Economics 8: 704-715. - doi: 10.1016/j.forpol.2005.06.011

Kurz HD (2010). Innovation, knowledge and growth: Adam Smith, Schumpeter and the moderns. Routledge, London, UK.

Làskovà J, Posavec S (2011). Forest management in Croatia focusing on innovation. Forestry Journal 57 (2): 134-142. [online] URL: http://www.nlcsk.sk/files/2326.pdf

Likert R (1932). A technique for the measurement of attitudes. Archives of Psychology 22: 1-55.

Lunnan A, Nybakk E, Vennesland B (2006). Entrepreneurial attitudes and probability for startups - an investigation of Norwegian non-industrial private forest owners. Forest Policy and Economics 8: 683-690. - doi: 10.1016/j.forpol. 2005.06.016

Malerba F (2000). Economia dell'innovazione. Carocci Ed, Rome, Italy.

Niskanen A, Pettenella D, Slee B. (2007). Barriers and opportunities for the development of smallscale forest enterprises in Europe. Small-scale Forestry 6: 331-345. - doi: 10.1007/s11842-0079035-x

Notaro S, Gios G, Paletto A (2006). Using the contingent valuation method for ex ante service innovation evaluation. Swiss Forestry Journal
11: 507-512. - doi: 10.3188/szf.2006.0507

Rametsteiner E, Weiss E, Kubeczko K (2005). Innovation and entrepreneurship in forestry in Central Europe. Koninklijke Brill NV, Leiden. The Netherlands.

Rametsteiner E, Weiss E (2006a). Innovation and innovation policy in forestry: linking innovation process with systems models. Forest Policy and Economics 8: 691-703. - doi: 10.1016/j.forpol. 2005.06.009

Rametsteiner E, Weiss E (2006b). Assessing policies from a systems perspective - experiences with applied innovation systems analysis and implications for policy evaluation. Forest Policy and Economics 8: 564-576. - doi: 10.1016/j.forpol.2005.07.005

Redford KH, Adams WM (2009). Payment for ecosystem services and the challenge of saving nature. Conservation Biology 4: 785-787. - doi: 10.1111/j.1523-1739.2009.01271.x

Rogers EM (2002). Diffusion of preventive innovations. Addictive Behaviors 27(6): 989-993. doi: 10.1016/S0306-4603(02)00300-3

Rogers EM (2003). Diffusion of innovations. Free Press, New York, USA.

Sálka J, Longauer R, Lacko M (2006). The effects of property transformation on forestry entrepreneurship and innovation in the context of Slovakia. Forest Policy and Economics 8: 716-724. - doi: 10.1016/j.forpol.2005.06.017

Schumpeter J (1911). The theory of economic development. Harvard economic studies, vol. XLVI, Harvard University Press, Cambridge, MA, USA. English edition 1934.

Slee B (2011). Innovation in forest-related territorial goods and services: an introduction. In "Innovation in forestry. Territorial and value chain relationships" (Weiss G, Pettenella D, Ollonqvist P, Slee B eds). CABI International, Wallingford, USA.

Smale MC, Hall GMJ, Gardner RO (1995). Dynamics of Kanuka (Kunzea ericoides) forest on South Kaipara spit, New Zealand, and the impact of fallow deer (Dama dama). New Zealand Journal of Ecology 19 (2): 131-141. [online] URL: http://www.nzes.org.nz/nzje/free_issues/ NZJEcol19 2 131.pdf

Solow RM (1957). Technical change and the aggregate production function. Review of Economics and Statistics 39: 312-320. - doi: 10.2307/ 1926047

Utterback J, Abernathy W (1975). A dynamic model of process and product innovation. OMEGA 3: 639-656. - doi: 10.1016/0305-0483 (75)90068-7

Weber M, Hemmelskamp J (2005). Towards environmental innovation systems. Springer, Berlin, Germany. 